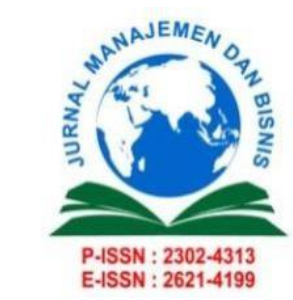

\author{
Jurnal Manajemen dan Bisnis \\ Vol. 10, No. 2, December 2021, pp. 55-67 \\ Sekolah Tinggi Ilmu Ekonomi Indragiri (STIE-I) Rengat \\ https://journal.stieindragiri.ac.id/index.php/jmbi/issue/view/20
}

\title{
IMPACT OF MEMBER'S DEPOSITS AND MEMBER'S LOANS ON THE REST OF BUSINESS PROFITS ON COOPERATIVE PARTNER MANDIRI, LIRIK DISTRICTS, INDRAGIRI HULU
}

\author{
Suharmiyati ${ }^{1)}$, Yenny Iskandar') \\ 1) 2) Management Study Program, Economics College of Indragiri Rengat \\ 14, R. Soeprapto St., Rengat, Indragiri Hulu, Riau \\ suharmiyati@stieindragiri.ac.id ${ }^{1)}$ yennyiskandar@stieindragiri.ac.id ${ }^{2)}$ \\ Submited: 2021.11.13 Reviewed: 2021.11.20 Accepted: 2021.12.31 \\ https://doi.org/10.34006/jmbi.v10i2.341
}

\begin{abstract}
The purpose of this study was to gain an understanding of the savings and loan cooperatives as a whole. Apparently savings and loan cooperatives are an important part of the Indonesian economy and can be beneficial for the lives of members. So, this study aims to determine the implementation of savings and loan cooperative procedures from all parties, problems and benefits. Therefore, the main research method is interview. This study shows that the use of savings and loan cooperatives can provide solutions for speed, accuracy and accuracy in carrying out saving and loan data processing in order to get optimal results. So this cooperative was established for member savings, member loans and there will be a distribution of SHU for all members.The Mitra Mandiri Cooperative, Lirik Districts, which is located in the Lirik sub-district, was established in 2012, but since 2012 it has developed until now. The loan process is based on a joint responsibility system and most loans are used for education and additional business capital. Cooperative Mitra Mandiri Lirik Districts strives to empower its members and employees more strongly with regular education and training. Furthermore, there is recreation every year to encourage member approaches and emphasize a family atmosphere. One of the important parts of the Cooperative Mitra Mandiri Lirik Districts is Savings and Loans which has been rolled out until now running smoothly.
\end{abstract}

Keywords: Member Loans, Member Savings and SHU

Vol. 10, No. 2, December 2021, pp. 55-67 


\section{PRELIMINARY}

\section{A. BACKGROUND}

Indonesia as a country that continues to develop is supposed to improve the quality and competitiveness of the nation's economy so as not to be left behind by other countries. The government makes various efforts to improve the welfare of the community by implementing development policies in the economic sector. One of the activities carried out and developed through cooperatives.

According to Law No. 25 of 1992, cooperatives are business entities consisting of people or cooperative legal entities, based on the cooperative principle as a people's economic movement based on the principle of kinship. The main purpose of establishing a cooperative is to prevent the community from being trapped in the system of loan sharks or moneylenders.

Cooperative is a business entity that is a legal entity with a business consisting of people who are oriented to produce added value that can be utilized to improve the welfare of its members. Companies that are able to provide profits and increase prosperity for their managers are companies that are successful in achieving their business goals(Suharmiyati \& Iskandar, 2020). In addition, cooperatives are also a people's economic movement because cooperatives prioritize the welfare of their members.

So the working principle of cooperatives is from the members and for the welfare of its members. The income from the business carried out by the cooperative and reduced by expenses is also called SHU or the remaining operating results. The remainder of the business results is then distributed fairly to each member without exception based on the capital and services provided by each member. So the greater the capital included or the more services a member performs, the greater the SHU he will receive. Often cooperatives face several obstacles. Problems that arise in terms of members whose growth is slow. This is due to the lack of member participation in information in the cooperative. Another problem arises in terms of member savings, Due to the limited capital available in the cooperative, it is difficult to develop the expected business units. In addition, lending is also limited because the capital is limited.

One of the cooperatives that stands in Lirik is the Mandiri Mitra Cooperative which has been doing several commercial businesses in order to get maximum profit or SHU. The business units that are run are the Savings and Loans Business Unit, Waserda, Transportation Services and Wholesale Services.

Therefore, the researcher would like to present a little financial report of the Cooperative Mitra Mandiri Lirik Districts regarding Member Loans, Member Savings and Remaining Operating Results for the period 2014 to 2020 sourced from the RAT book and the following table:

Table 1: $\quad$ Amount of Loans for Mitra Mandiri Cooperatives in Lirik Districts in 2014-2020.

\begin{tabular}{|c|c|c|}
\hline Year & Member Loan & \% growth \\
\hline 2014 & $413,497,500$ & - \\
\hline 2015 & 437.110 .244 & 5.71 \\
\hline 2016 & $375,651,736$ & $(14.06)$ \\
\hline 2017 & $738.010,000$ & 96.46 \\
\hline 2018 & 705.577 .000 & $(4.39)$ \\
\hline 2019 & $544.834,000$ & $(22.78)$ \\
\hline 2020 & $366,672,000$ & $(32.70)$ \\
\hline
\end{tabular}

Source: Cooperative Mitra Mandiri Lirik, Year 2020 
From the data above, we can see the size of the loan amount and the growth of the Mitra Mandiri Cooperative in the Lirik Districts in 2014-2020.

From the description of the table above, we can see that the number of loans from year to year has decreased and increased.

Table 2 : Total Member Savings and SHU of Mitra Mandiri Cooperative, Lirik Districts 20142020

\begin{tabular}{|c|c|c|c|c|}
\hline Year & $\begin{array}{c}\text { Member Savings } \\
\text { Amount }\end{array}$ & $\begin{array}{c}\text { Growth } \\
(\%)\end{array}$ & $\begin{array}{c}\text { Remaining Operating } \\
\text { Results (SHU) } \\
(\mathrm{Rp})\end{array}$ & $\begin{array}{c}\text { SHU Pertumbuhan } \\
\text { growth } \\
(\%)\end{array}$ \\
\hline 2014 & $927,828,975$ & - & $1,258,631,059$ & - \\
\hline 2015 & $868,896.171$ & $(6.35)$ & $1,134,277,505$ & $(9.88)$ \\
\hline 2016 & $1,068,910,256$ & 23.01 & $949,415,645$ & $(16.29)$ \\
\hline 2017 & 1.106 .125 .353 & 3.48 & 778.323 .233 & $(18.02)$ \\
\hline 2018 & $1.138 .137,055$ & 2.89 & $951,506.036$ & 22.25 \\
\hline 2019 & 1.312 .981 .485 & 15.36 & $847,693,329$ & $(10.91)$ \\
\hline 2020 & $1,278,370,966$ & $(2.63)$ & $318,748,324$ & $(62.39)$ \\
\hline
\end{tabular}

Source: Cooperative Mitra Mandiri Lyrics, Year 2020

From the data above, we can see the amount of savings and SHU and the growth of the Mandiri Mitra Mandiri Cooperative in the Lirik Districts in 2014-2020.

From the description of the table above, we can see that the number of remaining operating results from year to year has experienced growth and some has decreased. The income earned every year is inseparable from the four business units driven by the Mandiri Mitra Cooperative, namely the Savings and Loans Business Unit, Waserda, Transportation Services and Wholesale Services.]

\section{FORMULATION OF THE PROBLEM}

Do members' savings and member loans have a significant effect on the Remaining Revenue Earnings? Independent Partner Cooperative Lirik Districts Indragiri Hulu.

\section{RESEARCH PURPOSES}

To determine the effect of member savings and member loans on the acquisition of the remaining operating results in Independent Partner Cooperative Lirik Districts Indragiri Hulu.

\section{RESEARCH URGENCY}

The development of the Mitra Mandiri Cooperative, Lirik Districts, Indragiri Hulu has a positive impact on its members. Increasing the number of loans provided will help members to advance their business in order to improve a more decent standard of living. At least, with the Mitra Mandiri Cooperative, Lirik Districts, Indragiri Hulu, members are helped to finance children's education, business capital, and increase agricultural productivity so that they can increase family income. ]

\section{LITERATURE REVIEW}

\section{A. Remaining Operating Results}

The definition of remaining operating results according to Law No.25/1992, concerning cooperatives, CHAPTER IX article 45 is as follows:

1) Cooperative $\mathrm{SHU}$ is the cooperative's income earned in one financial year less costs, depreciation, and other obligations including taxes in the relevant financial year. 
2) SHU after deducting the reserve fund, is distributed to members in proportion to the business services performed by each member with the cooperative, and is used for cooperative education purposes and cooperative needs in accordance with the decision of the Member's Meeting.

3) The amount of capital accumulation for reserve funds is determined at the Members' Meeting

4) Determination of the amount of distribution to members and the type and amount determined by the Meeting of Members in accordance with the AD/ART of the Cooperative.

5) The amount of SHU received by each member will be different, depending on the amount of capital participation and member transactions towards the formation of cooperative income.

6) The greater the transaction (business and capital) of members with their cooperative, the greater the SHU that will be received.

7) In the calculation process, the member's SHU value can be done if some basic information is as follows:

- Total SHU of cooperatives in one financial year

- Share (percentage) of members' SHU

- Total savings of all members

- The total of all business transactions (business volume or turnover) originating from members

- Total deposit per member

- Turnover or business volume per member

- Share (percentage) of SHU for member savings

- Share (percentage) of SHU for member business transactions

$$
S H U=T R-T C
$$

TR : Total Revenue (Total Revenue)

TC : Total Cost (Total Cost)

Basically the SHU obtained by the cooperative every year is divided according to the rules set out in the Articles of Association / Bylaws of the cooperative in question. each member's efforts.

The Articles of Association of Cooperatives from the Ministry of Cooperatives and SMEs of the Republic of Indonesia explain that the distribution of SHU originating from businesses organized for cooperative members may only be distributed to members, while the remaining business results from cooperative businesses organized for non-members, for example from services against third parties may not be distributed to members because this part is not obtained from member services, this SHU is used for certain other financing.

\section{B. SAVINGS}

Savings as a term for cooperative investment was first used in Law 79 of 1958, namely the first cooperative law after independence. Since then until now the capital of cooperatives is savings. The term savings arose because of the strong recommendation to save, in the sense of cultivating capital for people who are generally less well off so that they are capable and independent.

According to Government Regulation No. 9 of 1995 member savings are funds that are trusted by members, prospective members, other cooperatives and or their members to cooperatives in the form of savings and term cooperative deposits. 
"Deposits are funds entrusted by the public to banks in the form of demand deposits, time deposits, certificates of deposit, savings or equivalents." (Hasan, 2014: 107).

\section{a. Types of Cooperative Savings}

1) Principal savings

An equal amount of deposit for each member can also be paid in installments. Principal savings can be taken back by the participant as long as he is a member of the cooperative.

2) Mandatory saving

Can be deposited weekly or monthly or according to the time set by the member. Deposits can be used for capital accumulation, special savings and mandatory loans from members who are willing, can also be used as investment capital accumulation.

3) Voluntary savings

Provide opportunities for members who can save in the form of deposits. Which can be taken according to the agreement.

Based on Law No. 24 of 2004, deposit insurance institutions have the following functions:

1) Guarantee customer deposits

2) Actively participate in maintaining system stability in accordance with the authority.

"Principal savings are deposits that have been determined in amount and are the same for each member." (Ninik Widiyati, 2010:114)

"Compulsory deposits are deposits that have been determined the amount must be kept by each member at certain times and on certain occasions." (Ninik Widiyanti, 2010:114)

"Voluntary term deposits are deposits that are made voluntarily, both in amount and in terms of time." (Ninik Widiyanti, 2010:114).

\section{LOAN}

According to Law No. 25 of 1992, it is stated that a loan is the provision of money or an equivalent claim, based on an agreement or loan agreement between a cooperative and another party that requires the borrower to repay his debt after a certain period of time accompanied by payment of a certain amount of compensation. .

"Credit is all types of loans that must be repaid with interest by the borrower in accordance with the agreed agreement." (Hasibuan, 2015:87)

"Credit is the provision of money or claims based on a loan agreement or agreement between a cooperative and another party that requires the borrowing party to repay its debt after a certain period of giving interest." ( Kasmir, 2014:84)

"Financing or credit is the provision of money or equivalent claims, based on an agreement and agreement between the bank and another party that requires the party being financed to return the money or claim after a certain period of time in exchange for interest or profit sharing." (Kashmir, 2016:73)

"Credit is the provision of money or an equivalent claim, based on a loan agreement or agreement between a bank and another party that requires the borrowing party to repay the debt after a certain period of time with interest." (Dendawijaya, 2009:17)

Based on some of these opinions, it can be concluded that Member Loans are funds collected by cooperatives from member savings which are distributed to borrowers which must be paid along with loan interest according to a predetermined 
agreement.

\section{STATE OF THE ART}

\begin{tabular}{|c|c|}
\hline Research Title & $\begin{array}{l}\text { The Effect of Member Savings and Loans on Remaining Operating Results (Shu) } \\
\text { Case Study in the Kopmen Bina Sejahtera Consumer Cooperative, Ciparay } \\
\text { District, 2011-2016 }\end{array}$ \\
\hline Researcher & $\begin{array}{l}\text { Muhammad Satar } \\
\text { Sri Wulan Sari (2011-2016) }\end{array}$ \\
\hline Year & 2016 \\
\hline Related Variables & Savings, Member Loans, Remaining Operating Results \\
\hline Findings & $\begin{array}{l}\text { Based on the results of the study: } \\
\text { 1) Member Savings does not have a significant effect on the Remaining } \\
\text { Operating Results, as indicated by the results of the t-test which are smaller than } \\
\text { t-table }(-1.886<3.182) \text {. } \\
\text { 2) Member Loans have no significant effect on the Remaining Operating Results, } \\
\text { indicated by the results of the t-test smaller than t-table }(2.593<3.182) \text {. } \\
\text { 3) Meanwhile, Simultaneously Savings and Loans of Members have no } \\
\text { significant effect on the Remaining Operating Results, as indicated by the result } \\
\text { of the f-test which is smaller than f table }(5.507<9.55) \text {. }\end{array}$ \\
\hline Equality & The research uses quantitative analysis. \\
\hline Difference & This research was conducted in different cooperatives \\
\hline Research Title & $\begin{array}{l}\text { Effect of Number of Members, Total Savings, Total Loans and Total Working } \\
\text { Capital on Remaining Operating Results (Shu) of Savings and Loans } \\
\text { Cooperatives (Ksp) in Badung Regency, Bali Province }\end{array}$ \\
\hline Researcher & Ni Made Taman Ayuk (2013) \\
\hline Year & 2013 \\
\hline Related Variables & Member loans and remaining operating results \\
\hline Findings & $\begin{array}{l}\text { Variables of the number of members, the number of savings, the number of loans } \\
\text { and the amount of working capital simultaneously have a significant effect on the } \\
\text { remaining operating results of savings and loan cooperatives in Badung Regency, } \\
\text { Bali Province. } \\
\text { 2) The variable number of members, the amount of working capital partially has } \\
\text { a positive and significant effect on the remaining results of the savings and loan } \\
\text { cooperatives in Badung Regency, Bali Province, while the variables of the } \\
\text { amount of savings and the amount of loans have no effect. 3) The variable amount } \\
\text { of working capital has the most dominant effect on the remaining results of } \\
\text { savings and loan cooperatives in Badung Regency, Bali Province. }\end{array}$ \\
\hline Equality & The research uses quantitative analysis. And using simple linear regression \\
\hline Difference & This research was conducted in different cooperatives \\
\hline Research Title & $\begin{array}{l}\text { The Effect of Principal Savings and Member Loans on Remaining Operating } \\
\text { Results at the Buan Endah Credit Cooperative for the 2009-2016 Period }\end{array}$ \\
\hline Researcher & Muhammad Iqbal Linda Widiya \\
\hline Year & 2018 \\
\hline Related Variables & Savings, Loans and Remaining Operating Results \\
\hline Findings & $\begin{array}{l}\text { Based on the results of the study, obtained } \\
\text { 1) the principal savings and loans of members have an effect on the remaining } \\
\text { operating results, meaning that the principal savings and loans of members have } \\
\text { a positive or significant effect on the remaining operating results. } \\
\text { 2) Principal Savings on Remaining Operating Results partially there is no } \\
\text { significant effect between principal savings and Remaining Operating Results. } \\
\text { 3) member loans have an effect on the remaining operating results partially there } \\
\text { is a significant effect between member loans and the remaining operating results }\end{array}$ \\
\hline
\end{tabular}




\begin{tabular}{|l|l|}
\hline Equality & The research uses quantitative analysis. And using multiple linear regression \\
\hline Difference & This research was conducted in different cooperatives \\
\hline
\end{tabular}

\section{RESEARCH RESULTS AND DISCUSSION}

\section{A. Classic assumption test}

\section{a. Normality test}

Normality test aims to test the data whether in the regression model the dependent variable and the independent variable both have a normal distribution or not. A good regression model is to have a normal or close to normal data distribution. The results of the normality test using histograms and probability plot graphs using SPSS version 23 for the budget realization variable are shown in the figure below.

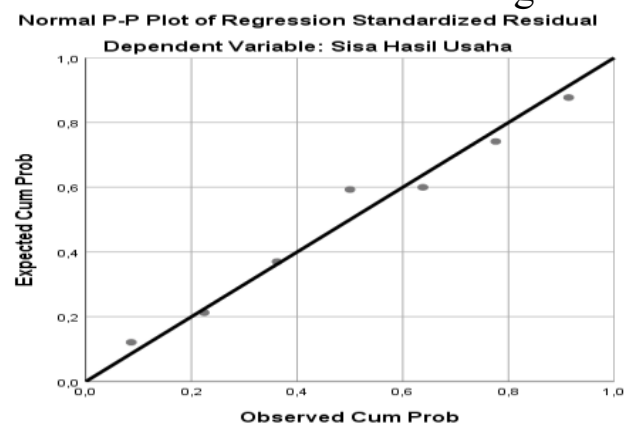

Based on the histogram graphic display, a normal curve line is obtained, meaning that the data studied above are normally distributed, while the picture above shows the scatter plot data that follows the diagonal line, meaning that the data follows normal data and is in accordance with the normality test.

\section{b. Heteroscedasticity test}

To determine heteroscedasticity assisted by the SPSS program. While the heteroscedasticity test in this study was carried out using a regression scatterplot. The heteroscedasticity test aims to test whether in the regression table there is an inequality of variance from the residuals of one observation to another observation. If the variance of the residuals from one observation to another is different, it is called Heteroscedasticity.

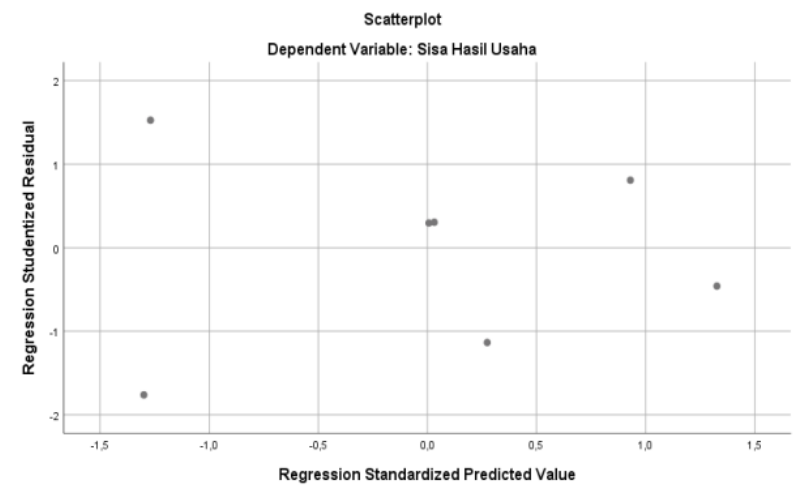

From the scatterplot image above, it can be seen that the points spread randomly do not form a clear specific pattern, and are spread above and below zero (0) on the Y axis. Therefore, it can be concluded that the regression model in this study does not contain any heteroscedasticity symptoms. 


\section{c. Multicollinearity Test}

Multicollinearity test is used to determine whether there is multicollinearity between independent variables or not. This test uses the product moment correlation technique. The interpretation is to look at the VIF (Variant Inflation Factor) and Tolerance values in the ordinary regression process, if both values are close to 1 or the VIF value is less than 10 then the model is not affected by multicollinearity.

\begin{tabular}{|ll|r|r|}
\hline \multicolumn{2}{|c|}{ Coefficientsa } \\
\hline \multirow{2}{*}{ Model } & \multicolumn{2}{|c|}{ Collinearity Statistics } \\
\hline 1 & & Tolerance & \multicolumn{1}{c|}{ VIF } \\
\cline { 3 - 4 } & (Constant) & .966 & 1.035 \\
& member loan & .966 & 1.035 \\
& member savings & & \\
\end{tabular}

a. Dependent Variable: remaining operating results

Source: SPSS 23 Processed Data

From the test results above, it can be seen that the VIF value is $1.035<10$ with a Tolerance value of $0.966>0.10$ so it can be concluded that the regression model in this study does not occur symptoms of multicollinearity between variables.

\section{d. Autocorrelation Test}

The autocorrelation test aims to test whether in a regression model there is a correlation between errors in the t-1 period. To find out the symptoms of autocorrelation, it can be tested with the Durbin Watson test. If the Durbin Watson value $>\mathrm{F}$ table, then there is no autocorrelation among the independent variables in the regression equation model.

\begin{tabular}{|l|l|r|r|r|r|}
\hline \multicolumn{6}{|c|}{ Model Summaryb } \\
\hline Model & $\mathrm{R}$ & R Square & Adjusted R Square & $\begin{array}{c}\text { Std. Error of the } \\
\text { Estimate }\end{array}$ & Durbin-Watson \\
\hline 1 &, $795 \mathrm{a}$ &, 631 &, 447 & 223817,84074 & 2,439 \\
\hline
\end{tabular}

a. Predictors: (Constant), Member Loan, Member Deposit

b. Dependent Variable: Remaining Operating Results

Based on the model summary table above, the Durbin Watson value is 2,439. Greater than the dU value of 1.8964 and less than 4-dU, there is no autocorrelation among the independent variables in the regression equation model.

B. Multiple Linear Regression Test

Coefficientsa

\begin{tabular}{|c|c|c|c|c|c|c|c|c|}
\hline \multirow{2}{*}{\multicolumn{2}{|c|}{ Model }} & \multicolumn{2}{|c|}{$\begin{array}{l}\text { Unstandardized } \\
\text { Coefficients }\end{array}$} & \multirow{3}{*}{$\begin{array}{c}\text { Standardized } \\
\text { Coefficients } \\
\text { Beta } \\
\end{array}$} & \multirow{3}{*}{$\frac{\mathrm{t}}{3,639}$} & \multirow{3}{*}{$\frac{\text { Sig. }}{, 022}$} & \multicolumn{2}{|c|}{ Collinearity Statistics } \\
\hline & & B & Std. Error & & & & Tolerance & VIF \\
\hline \multirow[t]{3}{*}{1} & (Constant) & 2348486.782 & 645415,378 & & & & & \\
\hline & Member Savings & $-1,477$ & ,565 &,- 808 & $-2,616$ & 0.059 & ,966 & 1.035 \\
\hline & Member Loan &, 328 &, 599 & ,169 &, 548 & ,613 & ,966 & 1.035 \\
\hline
\end{tabular}

a. Dependent Variable: Remaining Operating Results

Based on the table above, the following regression equation can be obtained:

$$
\begin{gathered}
Y=a+b 1 X 1+b 2 X 2 \\
Y=2348486.782-1.477 \times 1+0.328 \times 2
\end{gathered}
$$

The regression equation can be explained as follows:

1. constant. The constant value in this regression is 2348486.782 , which means that if the member's loan and member's savings are zero, the Remaining Operating Income (SHU) is worth 2348486.782 
2. The coefficient value of member savings is -1.477 , meaning that if member savings have increased by one unit, while the member loan variable is fixed or zero, it will decrease the remaining operating income (SHU) of -1.477 .

3 . The coefficient value of member loans is 0.328 , meaning that if member loans increase by one unit, while the member savings variable is fixed or zero, it will increase the remaining operating results (SHU) of 0.328 .

1. Standard Error (e) Is a random variable and has a probability distribution. The standard error (e) represents all factors that have an influence on $\mathrm{Y}$ but are not included in the equation.

\section{Multiple Linear Correlation Coefficient Analysis (R)}

Multiple correlation is used to determine the level of relationship between variables X1 and $\mathrm{X} 2$ on variable $\mathrm{Y}$. In this case the effect studied is the effect of member loans and member savings on the remaining operating results (SHU).

\begin{tabular}{|l|c|r|r|r|r|}
\hline \multicolumn{7}{|c|}{ Model Summaryb } \\
\hline Model & $\mathrm{R}$ & $\mathrm{R}$ Square & Adjusted R Square & $\begin{array}{c}\text { Std. Error of the } \\
\text { Estimate }\end{array}$ & Durbin-Watson \\
\hline 1 &, $795 \mathrm{a}$ &, 631 &, 447 & 223817,84074 & 2,439 \\
\hline
\end{tabular}

a. Predictors: (Constant), Member Loan, Member Deposit

b. Dependent Variable: Remaining Operating Results

$\begin{array}{cc}\text { Correlation Coefficient }(\mathrm{r}) & \text { Connection } \\ 0.00-0.199 & \text { Very weak } \\ 0.20-0.399 & \text { Weak } \\ 0.40-0.599 & \text { Currently } \\ 0.60-0.799 & \text { Strong } \\ 0.80-1.0 & \text { Very strong }\end{array}$

From these criteria, the correlation coefficient value of 0.795 is included in the criteria $(0.60-0.799)$ which means that it belongs to the category of Strong correlation. From the results of the calculation above, it shows the relationship between member loans and member savings to the remaining operating income (SHU) of 0.795 .

\section{Coefficient of Determination Analysis (R2)}

The coefficient of determination shows how many percent of the data variation (up and down) the dependent variable can be explained or explained by the variation of the independent variable. This can be seen from the model summary table as follows:

\begin{tabular}{|l|l|r|r|r|r|}
\hline \multicolumn{7}{|c|}{ Model Summaryb } \\
\hline Model & $\mathrm{R}$ & R Square & Adjusted R Square & $\begin{array}{c}\text { Std. Error of the } \\
\text { Estimate }\end{array}$ & Durbin-Watson \\
\hline 1 &, $795 a$ &, 631 &, 447 & 223817,84074 & 2,439 \\
\hline
\end{tabular}

a. Predictors: (Constant), Member Loan, Member Deposit

b. Dependent Variable: Remaining Operating Results

From the table above, it can be seen that the R2 value is 0.595 and $\mathrm{R}$ square explains how much influence the independent variable has on the dependent variable can be seen from the magnitude of the coefficient of determination (R2), which differs between zero and one. Variations in Remaining Operating Results are caused by Member Savings and Member Loans from the calculation results obtained by the R2 value of 0.795 or $79.5 \%$. This means that $79.5 \%$ of the remaining operating income (SHU) is influenced by the two independent variables, while the remaining $20.5 \%$ is influenced by other factors not examined in this study. 


\section{E. Hypothesis test}

\section{Simultaneous Test (F Test)}

The $\mathrm{F}$ test or the regression coefficient test simultaneously is to determine the effect of the independent variables simultaneously, namely to determine the effect of the independent variables simultaneously on the dependent variable, whether it has a significant effect or not. The calculation of the hypothesis test using the SPSS program with the following calculation results:

ANOVAa

\begin{tabular}{|l|l|l|r|r|r|c|}
\hline \multicolumn{2}{|l|}{ Model } & Sum of Squares & df & Mean Square & F & Sig. \\
\hline \multicolumn{1}{|l|}{1} & Regression & 343075427375.527 & 2 & 171537713687,763 & 3,424 &, $136 \mathrm{~b}$ \\
\cline { 2 - 7 } & Residual & 200377703336,188 & 4 & 50094425834,047 & & \\
\cline { 2 - 8 } & Total & 543453130711,714 & 6 & & & \\
\hline
\end{tabular}

a. Dependent Variable: Remaining Operating Results

b. Predictors: (Constant), Member Loan, Member Deposit

Ftable: 6.94

Fcount: 3,424

Significant: 0.136

Based on the results of the simultaneous test, it is known that the Fcount is 3.424 with a significance of 0.136 and the Ftable is 6.94. The effect of the independent variable on the dependent variable was tested with a significance level of confidence of 0.05 with the test criteria.

The test tool used to accept or reject the hypothesis is the F statistical test, provided that if $\mathrm{F}_{\text {count }}>$ Ftable then $\mathrm{Ho}$ is rejected and $\mathrm{Ha}$ is accepted and vice versa if Fcount $<$ Ftable then Ho is accepted and $\mathrm{Ha}$ is rejected. While the results of the $\mathrm{F}$ test show that Fcount < Ftable $(3,424<6,94)$.

2. Partial Test Or t Test

\begin{tabular}{|c|c|c|c|c|c|c|c|c|}
\hline \\
\hline \multirow{2}{*}{\multicolumn{2}{|c|}{ Model }} & \multicolumn{2}{|c|}{ Unstandardized Coefficients } & \multirow{3}{*}{$\begin{array}{c}\text { Standardized } \\
\text { Coefficients }\end{array}$} & \multirow[t]{2}{*}{$\mathrm{t}$} & \multirow[t]{2}{*}{ Sig. } & \multicolumn{2}{|c|}{ Collinearity Statistics } \\
\hline & & $\mathrm{B}$ & Std. Error & & & & Tolerance & VIF \\
\hline \multirow[t]{3}{*}{1} & (Constant) & 2348486.782 & 645415,378 & & 3,639 & ,022 & & \\
\hline & Member Savings & $-1,477$ & ,565 &,- 808 & $-2,616$ & $\begin{array}{r}0.05 \\
9 \\
\end{array}$ & ,966 & 1.035 \\
\hline & Member Loan & ,328 & ,599 & , 169 & 548 & ,613 & ,966 & 1.035 \\
\hline
\end{tabular}

a. Dependent Variable: Remaining Operating Results

$\begin{array}{ll}\mathrm{t}_{\text {table }} & =2.77645 \\ \text { tcount } \mathrm{x}_{1} & =-2,616 \\ \text { tcount } \mathrm{x}_{2} & =0.548 \\ \text { Significant } \mathrm{X}_{1} & =0.059 \\ \text { Significant } \mathrm{X}_{2} & =0.613\end{array}$

\section{a. Partial Test of Member Savings (X1)}

Based on the table above, it can be seen the value of tcount for the member savings variable is $-2,616$ while the ttable value is 2,77645 with a significance level of 0,059 then the result is the tcount $>$ ttable which is $-2,616>-2,77645$, based on the data testing criteria it can be seen that $\mathrm{Ha}$ is accepted and Ho is rejected which means savings members partially have a significant effect on the Remaining Operating Results (SHU). 


\section{b. Member Loan Partial Test (X2)}

Based on the table above, we can see that the tcount value for the member loan variable is tcount 0.548 while the ttable value is 2.77645 with a significance level of 0.613 . So the results are tcount $<$ ttable, namely $0.548<2.77645$ with a significant value greater than the significance level of $0.613<0.005$. So based on the data testing criteria, it can be seen that Ho is accepted and $\mathrm{Ha}$ is rejected, which means that the member's loan partially has no effect on the Remaining Operating Results (SHU).

\section{CONCLUSIONS AND SUGGESTIONS}

\section{A. Conclusion}

1. Variables of member savings, member loans simultaneously have a significant effect on the remaining operating results of the Mitra Mandiri Cooperative, Lirik Districts.

2. Member Savings Variable partially positive and significant effect on the remaining results of the savings and loan cooperatives in the Mitra Mandiri Cooperative, Lirik Districts.

3. While the member loan variable partially has no effect on the remaining results of the savings and loan cooperatives in the Mitra Mandiri Cooperative, Lirik Districts.

\section{B. Suggestion}

1. The development of member loans fluctuated. so that cooperatives can increase the number of loans by reducing interest and administrative costs. If the interest and administrative costs are reduced, it is hoped that members will want to make loans so that the cooperative will earn interest which will increase the amount of remaining business results obtained.

2. The development of member deposits fluctuated. so that cooperatives can increase the amount of savings as capital in providing loans so that with large capital, cooperatives will grow.

3. The development of the remaining operating results fluctuates every year. Because the remaining operating results are the difference between income and expenses incurred, to increase the remaining operating results, the cooperative urges all members of the cooperative to play an active role both in savings and loans, as well as all existing businesses in the cooperative so that the number of deposits increases on the other hand, the amount of income increases and the remaining operating results to be distributed to members will increase.

\section{REFERENCES}

April Liana, 2009, Factors Affecting Remaining Operating Results at the Waru Buana Putra Cooperative in Sidoarjo. Journal of Economics. Through Ventures. Vol.1 No 2 April 2000.

Dewi, Puspa and Syafrizal, 2015, Cooperative Management, Baduose Media, Jakarta.

Dendawijaya, Lukman, Banking Management, Ghalia Indonesia, Jakarta.

Ferline Ariesta, 2014, The Influence of Number of Members and Savings of Members on 
Increasing Operating Income (Shu) at Pkp-Ri (Center for Cooperative Employees of the Republic of Indonesia) West Sumatra Province. Journal of Economics Vol.2 (116-125).

Hasibuan, Malay SP, 2011, Human Resource Management, PT. Earth Literacy, Jakarta.

Hasan, 2014, Marketing and Choice Cases, CAPS, Yogyakarta

Hendrojogi, 2012, Cooperatives: Principles, theory and practice, Rajawali Pers, Jakarta.

Kasmir, 2014, Financial Statement Analysis, PT. Rajagrafindo Persada, Jakarta.

Kartasapoetra, AG et al, 2013, Cooperative Management Practice, Rineka Cipta, Jakarta.

Kotler, Philip and Keller, Kevin Lane, 2009, Marketing Management, Volume I, Twelfth Edition, PT. Index, Jakarta.

Muhammad Iqbal, Linda Widya, 2018, Effect of Principal Savings and Member Loans on Remaining Operating Results at the Buanan Endah Credit Cooperative, Journal of Accounting Volume 9, Number 3, pp. 65-86.

Muhammad Satar, Sri Wulan Sari, 2016, Effect of Member Savings and Loans on Remaining Operating Results (Shu) Case Study on the Consumer Cooperative KOPMEN Bina Sejahtera, Volume 10, Number 2, pp. 80-92.

Ni Made Taman Ayuk, 2013, Effect of Number of Members, Total Savings, Total Loans and Working Capital on the Remaining Profits of Savings and Loan Cooperatives, Badung Regency, Bali Province.

Sinar Graphic Editorial, Cooperative Law No. 25 of 1992.

Rudianto, 2010, Cooperative Accounting, Erlangga, Jakarta.

Sudarwanto, Adenk, 2013, Cooperative Accounting (Practical Approach to Preparation of Financial Statements), Graha Ilmu, Yogyakarta.

Suharmiyati, S., \& Iskandar, Y. (2020). Effect of Current Ratio on Return on Assets at Bumdesa Lancang Kuning, Rumbai Jaya Village, Kempas District, Indragiri Hilir Regency, Riau. J-MAS (Journal of Management and Science), 5(1), 38. https://doi.org/10.33087/jmas.v5i1.145

Sugiyarso, Gervasius, 2011, Cooperative Accounting Systems, Methods, and Analysis of Financial Statements, Caps, Yogyakarta.

Sugiyono, 2010, Qualitative Quantitative Research Methods and R\&D, CV. Alphabeta, Bandung.

Law of the Republic of Indonesia Number 17 of 2012 
Widiyant, Ninik, 2012, Cooperative Management, Rineka Cipta, Jakarta.

The bibliography is compiled and written based on a number system in accordance with the citation order. Only the references cited in the research proposal are listed in the Bibliography. And I suggest using a Mendeley tool or something. 